\title{
RECOVERY FROM ANAESTHESIA IN OUTPATIENTS: A COMPARISON OF NARCOTIC AND INHALATIONAL TECHNIQUES
}

\author{
A.C. Enright and A. Pace-Floridia
}

WITH THE EVER-GROWING NUMBER of surgical procedures performed on outpatients, recovery time from anaesthesia is becoming of increasing importance. This study was undertaken to determine if there is any significant difference in recovery time between patients who receive inhalational anaesthesia and those who receive narcotics.

\section{METHODS}

Forty-one consecutive patients from the outpatient surgical list were studied. All underwent minor surgical procedures. All patients were premedicated with meperidine and atropine (see Table II). All patients were induced with thiopentone and maintained on nitrous oxide and oxygen. Supplementary agents were added at the discretion of each anaesthetist. Fourteen patients received halothane, four enflurane, and one methoxyflurane. Five patients received meperidine, fourteen fentanyl and five a combination of fentanyl with droperidol (see Tables I and II for details of both groups ).

TABLE I

Detalls of Patients: Number, Means, Standard Deviation, p Values of Age and WEIGHT

\begin{tabular}{lccc}
\hline & Volatile & Narcotic & p value \\
\hline Number of patients & 19 & 22 & \\
Mean age & $35.6 \pm 10.7$ years & $36.5 \pm 9.7$ years & $\mathrm{p}<0.9^{*}$ \\
Mean weight & $73.5 \pm 20.4 \mathrm{Kg}$ & $65.5 \pm 11.5 \mathrm{Kg}$ & $\mathrm{p}<0.2^{*}$ \\
\hline
\end{tabular}

*Not significant.

TABLE II

Details of Anaesthesia: Means, Standard Deviations, p Values of Premedication, Induction DOSE OF Thiopentone and Duration of AnaEsthesta

\begin{tabular}{lrrr}
\hline & Volatile & Narcotic & p value \\
\hline Mean dose meperidine & $55.2 \pm 11.3 \mathrm{mg}$ & $52.7 \pm 7.5 \mathrm{mg}$ & $\mathrm{p}<0.5^{*}$ \\
Mean dose thiopentone & $405.2 \pm 94.1 \mathrm{mg}$ & $372.7 \pm 10.1 \mathrm{mg}$ & $\mathrm{p}<0.3^{*}$ \\
Mean time anaesthesia & $31.3 \pm 12.5 \mathrm{~min}$ & $21.7 \pm 13.0 \mathrm{~min}$ & $\mathrm{p}<0.05 \dagger$ \\
\hline *Not significant. & & & \\
†Significant. & & &
\end{tabular}

A.C. Enright, M.B., B.Ch., Resident in Anaesthesia, A. Pace-Floridia, M.D., F.R.C.P.(C), Assistant Professor of Anaesthesia, Department of Anaesthesia, Holy Cross Hospital and The University of Calgary. 
INSTRUCTIONS: Please connect the dots on the figure outlined immediately below.

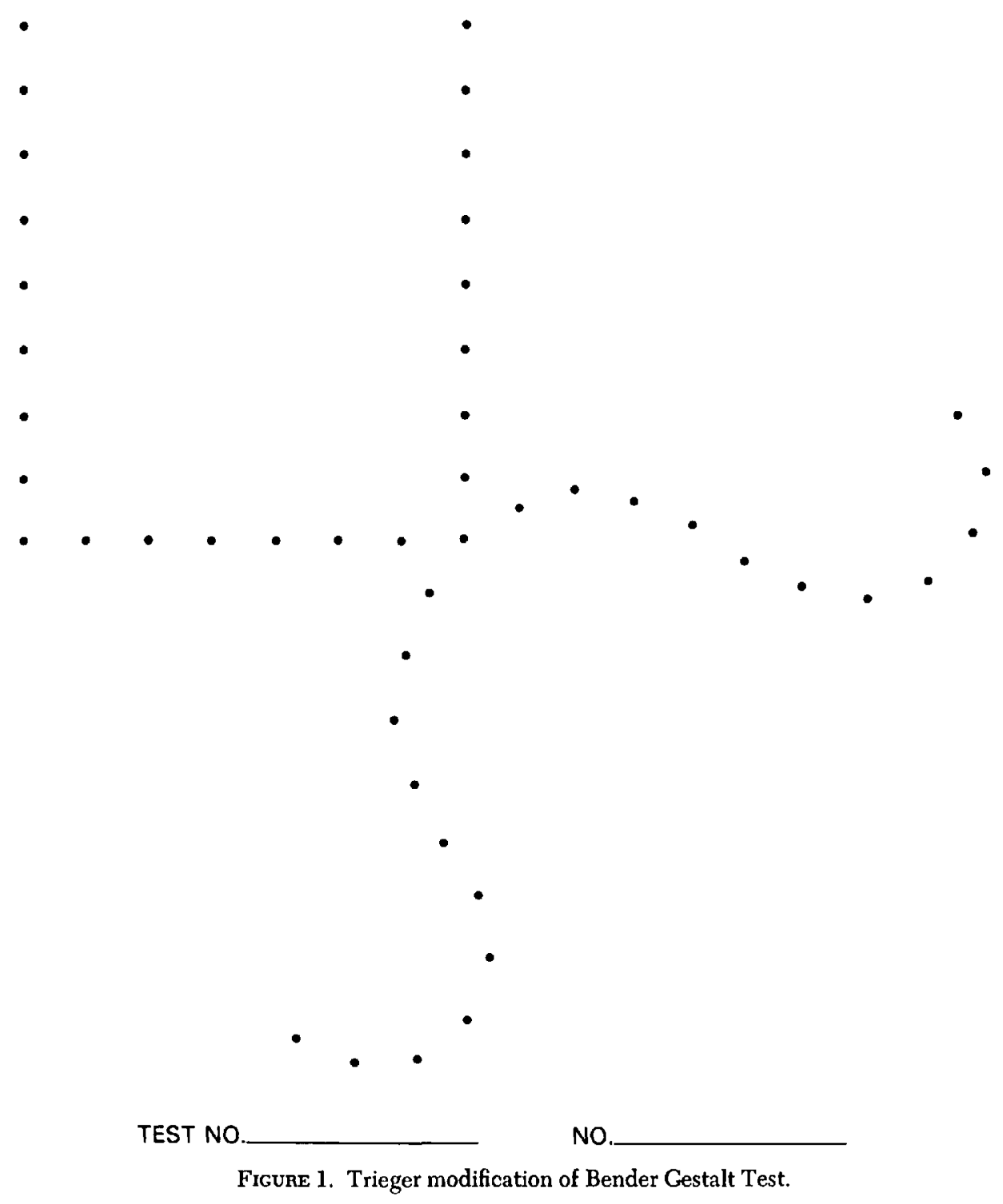

The Trieger modification of the Bender Gestalt Test was used to measure recovery from anaesthesia (Figure 1).${ }^{1}$ This reference contains the scoring details. Each patient completed a baseline test prior to premedication. Following operation and a period in the recovery room, the patients returned to a short-stay room. The time spent in the recovery room is reflected in the number of patients taking 
TABLE III

Details of Scores: Means, Standard Deviation, p Values of Scores for the Two Groups. (Number of Patients Taking Each Test in Parentheses)

\begin{tabular}{lrrr}
\hline \hline & Volatile & Narcotic & p value \\
\hline Baseline (before & & & \\
premedication) & $2.68 \pm 2.61(19)$ & $1.45 \pm 2.38(22)$ & $\mathrm{p}<0.2^{*}$ \\
$30-59$ min post op & $10.75 \pm 9.88(16)$ & $29.05 \pm 18.49(19)$ & $\mathrm{p}<0.005 \dagger$ \\
$60-89$ min post op & $8.63 \pm 8.60(19)$ & $10.04 \pm 8.79(22)$ & $\mathrm{p}<0.7^{*}$ \\
$90-119$ min post op & $6.84 \pm 9.30(19)$ & $6.70 \pm 7.77(20)$ & $\mathrm{p}<0.975^{*}$ \\
$120-149$ min post op & $10.00 \pm 6.98(8)$ & $10.54 \pm 9.73(11)$ & $\mathrm{p}<0.95^{*}$ \\
\hline
\end{tabular}

*Not significant.

†Significant.

the test in the first 90 minutes postoperatively. All scores were timed from the termination of anaesthesia. No scores were recorded in the first thirty minutes after operation.

Each patient completed the test on arrival in the short-stay room and at 15 minute intervals till discharge or for. 150 minutes, whichever was the lesser. Note was made of patient position and allowance made in scoring, if necessary. A perfect score was zero. All scoring was done by one person (A.E.). Scores were recorded as absolute figures, not as deviations from the baseline. Statistical significance of the results was determined using a modification of Student's t-test. A $p$ value of less than 0.05 was considered significant.

\section{Results}

The two groups were comparable with respect to age, weight, premedication dose of meperidine and induction dose of thiopentone. There was no significant difference in the baseline score for each group. At 30 to 59 minutes post-operatively patients who received inhalation agents performed significantly better than did patients who received narcotics $(p<0.005)$, in spite of the fact that the duration of their operation was significantly longer than the narcotics group ( $p<$ 0.05 ) (see Tables I and III). There were some individuals in each group who scored poorly at 150 minutes. However, there was no significant difference between the two groups.

\section{Discussion}

The concept of outpatient surgery is now well established. ${ }^{2-5}$ Many studies have reviewed suitable agents for use in outpatients. ${ }^{6-12}$ There has been concern over slow or delayed recovery from anaesthesia, especially in relationship to patient safety. ${ }^{13-17}$ This study considered only the broad subgroups of narcotic and inhalational anaesthesia. It is recognized that a much larger study must be undertaken to evaluate individual agents.

Our study showed that patients who received inhalation anaesthetics performed significantly better at 30 to 59 minutes post-operatively than did patients who 
received narcotics. We suggest that if patients are to be discharged within one hour of operation, the anaesthetist should avoid the use of narcotics. This could be of importance in dental or high volume practices. After one hour, scores were essentially the same for both groups. We considered a score of within \pm 5 of the baseline as indicating recovery. This is arbitrary, however, and requires further evaluation. It is interesting that these scores correlated well with the judgment of the nursing staff and the feelings of the patients concerning discharge.

Nineteen patients remained till 150 minutes post-operatively. These may be in a "slow-to-recover" group. They could also be exhibiting the delayed effects of anaesthesia. These patients require careful supervision on discharge. It is clear that one cannot fix an arbitrary time for discharge of patients. Assessment must be on an individual basis. Several studies have outlined the type of delayed effects that can occur. ${ }^{18,19}$ The recommendations that patients be accompanied home and refrain from driving or making important decisions for 24 hours post-operatively, seem valid. ${ }^{20}$

\section{SUMMARY}

Forty-one patients undergoing outpatient anaesthesia and operation were studied. Nineteen received inhalation agents. Twenty-two received narcotics. Up to one hour post-operatively, patients who received inhalation anaesthesia performed significantly better than did those who received narcotics. After 60 minutes there was no significant difference between the two groups. It is suggested that narcotics be avoided in patients who will be discharged within one hour of anaesthesia. A small number of patients exhibited slow recovery. It is suggested that these may be patients at risk and that special care be exercised.

\section{RÉSUMÉ}

Quarante-et-un patients opérés sur base externe ont été évalués au point de vue récupération après l’anesthésie générale.

Tous avaient reçu en prémédication de la mépéridine et de l'atropine; on leur avait administré du thiopenthal comme agent d'induction. En supplément au mélange protoxyde d'azote-oxygène, 19 malades avaient reçu un anesthésique d'inhalation (halothane, enflurane ou methoxyflurane) alors que les 21 autres patients avaient reçu des narcotiques intraveineux.

Les patients qui ont reçu des anesthésiques d'inhalation ont récupéré beaucoup plus rapidement au cours de la première heure. Cependant, une heure après la fin de l'anesthésie, les malades des deux groupes ne montraient pas de différence significative. Il est donc suggéré d'éviter les narcotiques chez les malades qu'on veut libérer moins d'une heure après la fin de l'intervention.

Pour un petit nombre de patients (19/41) des deux groupes, le temps de récupération a été plus long que celui de la moyenne. Il est suggéré de les considérer comme des patients à risque plus élevé et d'apporter une attention spéciale à leur examen de départ. 
Generic and trade names of drugs

$\begin{array}{ll}\text { Halothane } & \text { - Halothane } \\ \text { Enflurane } & \text { - Ethrane } \\ \text { Methoxyflurane } & - \text { Penthrane } \\ \text { Meperidine } & \text { - Demerol } \\ \text { Fentanyl } & \text { - Sublimaze } \\ \text { Fentanyl and Droperidol } & \text { - Innovar }\end{array}$

\section{ACKNOWLEDGEMENTS}

The authors wish to thank the following for their assistance in the completion of this project: Mrs. C. Roberts, R.N., Head Nurse; Nursing Staff of Recovery and Short-Stay Rooms, Holy Cross Hospital; Miss Karen Gorman.

\section{REFERENCES}

1. Newman, M.G., Triegen, N., Millen, J.C. Measuring recovery from anaesthesia: a simple test. Anesth. \& Analg. 48: 136-140 (1969).

2. Lieberman, S.L., Giacoia, E.B., \& Fedak, M. Hospital-based outpatient surgery: anesthesia experiences. N.Y. State I. Med. 75: 437-441 (1975).

3. Thompson, G.E., Remington, J.M., Millman, B.S., \& Bridenbaugh, L.D. Experiences with outpatient anesthesia. Anesth. \& Analg. 52: 881-887 (1973).

4. Treloan, E.J. An outpatient anaesthetic service: standards and organization. Can. Anaes. Soc. J. 14: 596-604 (1967).

5. STEwaRd, D.J. Experiences with an outpatient anaesthesia service for children. Anesth, \& Analg. 52: 877-880 (1973).

6. Thieger, N. \& Lasner, J. Entlurane ambulatory anesthesia: recovery compared to intravenous anesthesia. Anesth. Prog. 22 (1975).

7. Tregen, N., Loskota, W.J., Jacobs, A.W., \& Newman, M.G. Nitrous oxide; a study of physiological and psychological motor effects. J. Am. Dent. Ass. 82: 142-150 (1971).

8. Gale, G.D. Recovery from methohexitone, halothane and diazepam. Br. J. Anaesth. 48: 691-698 (1976).

9. Burnheis, R.B., Terny, P.M., \& Herhon, J.T. Comparative recovery of mental functions after electroconvulsive therapy with methohexital and thiopentone anaesthesia. Med. J. Austr. 625-627 (1966).

10. Newman, M.G., Trieger, N., Loskota, W.J., \& Jacons, A.W. A comparative study of psichomotor effects of intravenous agents used in dentistry. Oral. Surg. 30:34-40 (1970),

11. Editonial. Brief anaesthesia and recovery, Lancet 2: 1193 (1975).

12. Green, R., Long, H.A., Elliott, C.J.R., \& Howells, T.H. A method of studying recovery after anesthesia. Anaesthesia 18: 189-200 (1963).

13. OGG, T.S. An assessment of post-operative outpatient cases. Br. Med. J. 4: 573-576 (1972).

14. Konttila, K., Mattila, M.G., \& Linnoila, M. Prolonged recovery after diazepam sedation: the influence of food, charcoal ingestion and injection rate on the effects of intravenous diazepam. Br. J. Anaesth. 48; 333-340 (1976).

15. Dixon, R.A. \& Thornton, J.A. Tests of recovery from anaesthesia and sedation: intravenous diazepam in dentistry. Br. J. Anaesth. 45: 207-215 (1973).

16. VICkers, M.D. The measurement of recovery from anaesthesia. Br. J. Anaesth. 37: 296-302 (1965).

17. Doenicke, A., Kuglen, J., \& Laub, M. Evaluation of recovery and "Street Fitness" by EEG and psychodiagnostic tests after anaesthesia. Can. Anaes. Soc. J. 14: 567-583 (1967).

18. Becker, L.D., Paulson, B.A., Miller, R.D., Severinghaus, J.W., \& Eger, E.I. Biphasic respiratory depression after fentanyl-droperidol or fentanyl alone used to supplement nitrous oxide anesthesia. Anesthesiology 44: 291-296 (1976).

19. Konttila, K., Linnoila, M., Entama, P., \& Häknines, S. Recovery and simulated driving after intravenous anesthesia with thiopental, methohexital, propanidid, or alphadione. Anesthesiology 43: 291-299 (1975).

20. Brinde, G.F. \& Solman, M.G. Anaesthetic complications in surgical outpatients. Can. Anaes. Soc. J. 22: 613-619 (1975). 